\title{
Criminal Sanctions On Illegal Logging Crime In State Court Of Semarang
}

\author{
Muslich Ashari ${ }^{1}$, Amin Purnawan ${ }^{2}$ and Achmad Sulchan ${ }^{3}$
}

Abstract. The formulation of the problem discussed in this study were (1). How settings Criminal Law on Illegal logging?, (2). How Judges consideration in decisions on Illegal logging in State Court of Semarang?. (3). Are the constraints faced by the judge in deciding the case of Illegal logging?

This research used socio-juridical legal research, research data was taken by interview with the respondent judges handling crime of Illegal logging State Court of Semarang. This research use Qualitative analysis techniques.

Conclusion of this study is illegal logging is a special crime and therefore their specific legislation governing of illegal logging, in Act No. 18 of 2013 on Combating And Preventing The Destruction Of Forests set of sanctions for Illegal logging in the form of punishment imprisonment for the perpetrators in the form of a sentence of imprisonment and fines, consideration of Judges in deciding the case of Illegal logging legally is appropriate that the elements are there that the perpetrator does not have a valid license from the clerk to do cutting trees in the forest area of Silayur, Judge obstacle in deciding the case of Illegal logging in the form of difficulties in distinguishing between illegal logging carried out by individuals and corporations, lack of special education for judges to handle crime of Illegal Logging Keywords: Criminal Sanctions; Penalty; Illegal Logging.

\section{Introduction}

Semarang as a metropolitan city is certainly very difficult to get a job for the people who just tiered education was minimal, the economic factor is certainly the main reason for forest-dependent people who are in the area around Semarang are often felled timber for subsequent sale.

Soaring timber prices is the logical consequence of a breakthrough illegal curb logging, timber prices will definitely soar directly affects the swelling budget development projects ranging from the development of road infrastructure, educational facilities, to public housing. ${ }^{4}$

Combating illegal logging as a bitter prescription drug that certainly is not without side effects. Very high timber prices certainly tempting people living in forest areas, with the economic constraints of course, residents nearby forest for illegal logging. ${ }^{5}$

Forests are a very important resource not only as sources of timber, but rather as one of the components of the environment. Access and use rights on various categories of forests should be set up with a good idea for all groups in society by watching the aspect as in emphasize in Act No. 18 Of 2013 on the prevention and eradication of the destruction of forests Article 1, paragraph 9, which reads: "The utilization of forests is

\footnotetext{
${ }^{1}$ Student of Master of Law, Sultan Agung Islamic University (UNISSULA), Semarang, email: muslichashari30@gmail.com

${ }^{2}$ Lecturer of Master of Law, Sultan Agung Islamic University (UNISSULA), Semarang

${ }^{3}$ Lecturer of Master of Law, Sultan Agung Islamic University (UNISSULA), Semarang

${ }^{4}$ Zain Setia Alam, 2012. Hukum Lingkungan (Kaidah-kaidah Pengelolaan Hutan), Jakarta: Raja Grafindo Persada, p. 13

${ }^{5}$ Sukardi, 2010, Hukum Kehutanan \& Hukum Perkebunan di Indonesia, Jakarta: Sinar Grafika, p.24
} 
an activity for utilizing forest land, environmental services, timber and non-timber, as well as picking up timber and non-timber optimally and equitably for the benefit of society while maintaining sustainability", the article further stated that the implementation of forestry aimed at prosperity of the people with justice and sustainable. $^{6}$

Judging from the social aspect, Illegal logging caused various conflicts such as conflicts rights to the forest, the forest authority to manage the conflict between the central government and local governments and the indigenous population. Cultural aspects such as people's dependence on forests also affected which in turn will change the perspective and behavior of the local indigenous community forests. ${ }^{7}$

Background based on the description above, the writer interested in conducting research "Imposition of Criminal Crime against perpetrators of Illegal logging in State Court of Semarang"

Based on the above, the problems will be discussed as follows: How settings Criminal Law against criminal acts of Illegal Logging? How does a consideration in decisions Criminal Justice to perpetrators of Illegal Logging in the State Court of Semarang? And constraints faced by the judge in deciding the crime of Illegal Logging.

\section{Research Methods}

To complete this study in order to be more focused and can be justified scientifically, then the writing method used, among others. ${ }^{8}$

The method used is namely sociological juridical. The research was based on a legal provision and phenomena or events that occur in the field. Where his research type This study is descriptive analysis means authors conducted a study that aims to give a comprehensive picture of the facts and the legal issues, the legal system related to the object of research, then pulled a certain belief took this to a conclusion. ${ }^{9}$

The analysis in this journal writing using Qualitative analysis techniques that is to say where the data obtained and compiled systematically so that it will be obtained a comprehensive overview, in which the data will be presented in descriptive, With the expectation can be obtained comprehensive picture of the problems studied. ${ }^{10}$

\section{Results And Discussion}

\subsection{Criminal Law Regulation Against Illegal Logging}

The criminal action against forestry in this case is Illegal logging is a criminal offense specifically where there are criminal provisions that govern it, there are two criteria that may indicate criminal law special is the people or the subject is special and his

\footnotetext{
${ }^{6}$ Sukardi, 2010, Hukum Kehutanan \& Hukum Perkebunan di Indonesia, Jakarta: Sinar Grafika, p.34

${ }^{7}$ Dodik Ridho Nurrochmat. 2010, Strategi pengelolaan Hutan upaya penyelamatan hutan, Yogyakarta: pustaka pelajar, p. 118

${ }^{8}$ Soejono Soekanto, 2015, Pengantar Penelitian Hukum, Jakarta: UI Press, p. 43

${ }^{9}$ Soerjono Soekanto and Sri Mamudji, 2010, Penelitian Hukum Normatif Suatu Tinjauan Singkat, Jakarta: RajaGrafindo Persada, p.14.

${ }^{10}$ Eko Sugiarto, 2015, Menyusun Proposal Penelitian Kualitatif, Skripsi dan Tesis, Yogyakarta: Suaka Media, p. 9.
} 
action or object that is special (bijzonder lijk feiten), Crime of illegal logging is a criminal offense special category of criminal law special actions, for offenses concerning forestry timber forest product management. Therefore, the laws governing the matter is Act No. 18 of 2013 on the Prevention and Eradication of forest destruction. ${ }^{11}$

In the Act No. 18 of 2013 has set three types of sanctions that can be applied to the perpetrators who committed the crime or tort in forestry. The three types of sanctions provided for, include:

- Criminal sanctions (Article 82, Article 84, Article 94, Article 96, Article 97 letters a and b, Article 104, Article 105 or Article 106 of Act No. 18 of 2013);

- Administratively sanction form: government coercion, forcible money; and / or revocation of licenses (Article 18); and for the corporation an additional penalty may be imposed in the form of closing all or part of companies Article 109 paragraph (6);

- Additional penalty in the form: the form of the closure of all or part of the company. The fourth case will be explained as follows in accordance with Act No. 18 of 2013 on the Prevention and Combating of Forest Destruction

\subsection{Consideration Of Judge In The Verdict Against The Perpetrators Of The Crime Of Illegal Logging In State Court Of Semarang}

The role of the judge in deciding a matter of course, not carelessly, because the decision handed down to the defendant is certain and should be implemented, so judges should be viewed in terms of broad and thinking consequences arising from such decisions widely in order to benefit the people there in the state, the judge must be fair and reasonable, because in the decision handed down solely the openings to punish and sanction for the defendant but the law which was dug to prevent any recurrence, especially for the accused and in particular for the general public, a sense of justice must take precedence therefore, the judge must be fair.

Based on the results of interviews conducted by the author to the judges who decide the case as the presiding judge, Mr. Hakim Sartono in terms of sentencing for perpetrators of Illegal logging judges to consider several aspects other than those occurring in the hearing were: ${ }^{12}$

- The attitude of the perpetrators of Illegal logging That is, how many times the offender did Logging (Illegal logging) whether the offender to regret such actions and would not repeat his actions or not.

- Appeals and warnings to public. So that the people who live and around forests is prohibited and protected Act did Logging (illegal logging) in particular those in the region State Court of Semarang law and generally for the public at large in Indonesia.

\subsection{The Constraints Faced By the Judge In Deciding The Crime Of Illegal Logging}

\footnotetext{
${ }^{11}$ Salim HS2010, Dasar-Dasar Hukum Kehutanan (Revised Edition), Jakarta: Sinar Grafika, p.45

${ }^{12}$ personal interviews with respondents Assembly Presiding Judge, Hakim Sartono, State Court of Semarang.
} 
In deciding the case ever experienced criminal judges must act a constraint. Whether it is the constraints of internal self and the realm of the case at hand is too complicated for judges need the special training to master these cases are classified as special criminal. In this case the crime of Illegal logging is including a special criminal offense and therefore the judge had to master as well as a specially trained so that in deciding the case, it makes the deterrent effect to the community in doing Logging (illegal logging).

\section{Internal constraints}

Internal constraint is a constraint faced by judges from the self that is the strength of its existing the human power in deciding a case in providing legal certainty, the benefit of law and justice, based on your findings held internal constraint is composed as follows:

- Mastery of the law Ideally, a judge must master the science of law, development of legal science and master of cases handled, to master and therefore a judge would be given education and training in before performing his duties as a handle judges in handling cases in society in this regard judges must master the laws governing Illegal Logging, then of course should receive education and special training on Illegal Logging.

- Moral judge

Judges must have integrity and morality in providing justice and expediency, on the other hand the judge must be able to communicate well in order to be able to run the status and role so that accepted by the public, the judge must also have faith and piety to god almighty that is not easy in intervention by other parties who wish to benefit in the case addressed.

\section{External constraints}

External constraints are an obstacle judges in creating legal certainty, usefulness arising from outside the judges themselves, in this case some external constraints consist of:

- The system of judicial power.

Basically the justice system reform involves several aspects, ranging from revamping aspects of human resources, the increasing mastery the quality judge in the case of illegal logging, the special court that handles crime of Illegal logging and should their education were handling crime of Illegal logging.

- Formation Act.

The need for legislation that exists to tackle Illegal logging are held especially the rules governing the special court to handle crime of Illegal logging because illegal logging is a serious crime Just as corruption by a judge who handles should also get Special education in the field of illegal logging, hence the need for certification in doing the duties, in this case the need for regulations governing the supreme court judge certified about illegal logging, certification Just as the judge handling the case of the environment.

In this case the author has conducted research on whether the constraints faced by the judge in deciding the case of illegal logging In State Court of Semarang. Through which Judge authorities and has the task of deciding illegal logging of a state court of Semarang. 
Judge in deciding the case in the state court of Semarang is when the defendant committed an exception, the exception itself is objection submitted defendants in the trial, in addition to the obstacles faced by the judge is when the defendant made efforts namely Law Appeals. Because the judge alone in running the command Act does not have a legal basis in the case of illegal logging grip (illegal logging). Because of the lack of regulations governing the Supreme Court of Justice Special Logging (illegal logging) and there is no special training for the judge who handled the case.

Therefore felt the decision handed down is not in accordance with the losses suffered by the State, can't even distinguish between wild logging undertaken by the Corporation and those of individuals. In addition, based questions conveyed by researchers on how to distinguish between Illegal logging conducted by individuals and corporations, judges as the head judge handling the case of illegal logging, Mr. Hakim Sartono explained that the difference between Illegal logging that performed by individuals among others ${ }^{13}$ :

- The quantity of wood felled a small scale.

- The tools used are usually chainsaw manual.

- Carried out by residents who live near the forest area.

While Logging (illegal logging) conducted a corporation that is:

- The quantity of wood felled large scale.

- More modern tools used usually chainsaw (Senzo).

- Conducted by the corporation and usually involve the competent authorities in order to be eased.

\section{Closing}

\subsection{Conclusion}

- Settings criminal law concerning Illegal logging that illegal logging is a special crime and therefore their specific legislation governing of illegal logging, in Act No. 18 of 2013 on Combating And Preventing The Destruction Of Forests set of sanctions for Illegal logging in the form of a sentence of imprisonment for the perpetrators in the form of a sentence of imprisonment and fines.

- Judge consideration in deciding the case of Illegal logging legally is appropriate that the existing elements that the perpetrator does not have a valid license from the clerk to do cutting trees in the forest area of Silayur, the perpetrators are falling to organize for logging wild as well as in the form of trees felled evidence and the sentence imposed was in accordance with the losses that have been experienced by the country, as for the consideration that the defendant regretted his actions.

- The constraints judge in deciding crime of Illegal logging in the form of difficulties in distinguishing between illegal logging carried out by individuals and corporations, the lack of special education for judges to handle crime of Illegal logging and therefore sometimes still not able dismantle the corporate network that illegal logging had sent individuals to carry out Illegal Logging.

${ }^{13}$ Ibid. 


\subsection{Suggestion}

Based on the description above conclusions, the authors deliver the following suggestions:

- It is expected that the legislation on Illegal logging in order to clarify the number of trees to weight and severity of the penalty imposed for the illegal logging that as one of the more specific basis for the judge in sentencing.

- Expected government in authorized personnel capable of over jealous guard around forest area to participate oversee combat Illegal logging in a way to include people living in forest areas to patrol and provide rewards for local residents who are able to thwart Illegal logging so citizens eager to protect the forest from Illegal Logging.

- Held a special education for judges who handle crime of Illegal Logging, namely education in the room in the form of deepening of illegal logging crimes and in the field so that the judge can determine the condition of the forest after the occurrence of Illegal logging and the judge can determine the impact the impact that occurs as a result of illegal logging in the forest, as well as certification schemes for judges who handle crime of Illegal Logging.

\section{References}

\section{Books;}

[1] Zain Setia Alam, 2012, Hukum Lingkungan (Kaidah-kaidah Pengelolaan Hutan),Jakarta: Raja Grafindo Persada

[2] Dodik Ridho Nurrochmat. 2010, Strategi pengelolaan Hutan upaya penyelamatan hutan, Yogyakarta: pustaka pelajar

[3] Eko Sugiarto, 2015, Proposals Preparation Qualitative Research, Thesis and Thesis, Asylum Media, Yogyakarta

[4] Salim HS, 2010, Basics of Forestry Law (Revised Edition), Sinar Grafika, Jakarta.

[5] Soerjono Soekanto and Sri Mamudji, 2010, Penelitian Hukum Normatif Suatu Tinjauan Singkat, Jakarta: Raja Grafindo Persada

[6] Soejono Soekanto, 2015, Introduction to Legal Research, Jakarta: Pres UI

[7] Sukardi. 2010, Hukum Kehutanan \& Hukum Perkebunan di Indonesia, Jakarta: Sinar Grafika

\section{Legislation}

Act No. 18 of 2013 concerning the Prevention and Combating of Forest Destruction 